\title{
AN INTEGRATED STRATEGIC MANAGEMENT MODEL TO NAVIGATE THE ESTABLISHMENT OF TRANSPORT AUTHORITIES
}

\author{
CHRIS A. GELDENHUYS \\ LOUIS NAUDÉ \\ THEO H. VELDSMAN \\ Faculty: Economics and Management Sciences \\ Human Resource Management \\ Rand Afrikaans University
}

\begin{abstract}
This research covered the strategic intent for the transport industry and an overview of Transport Authorities in the municipal sphere of government. Representative sets of strategic management and change navigation models, as well as Swanepoel's (2001) model being used in the management of change in the public sector, were reviewed. An integrated strategic management model, which incorporates principles from strategic management and change navigation, is proposed for navigating the establishment of Transport Authorities. This model consists of six phases, namely: Awareness and Mobilisation; Strategic Synthesis and Choice; Strategy Crafting; Strategy Implementation; Performance Monitoring and Review; and Stabilisation. Recommendations follow regarding the validation of the model in a pilot project.
\end{abstract}

\section{OPSOMMING}

Hierdie navorsing het gefokus op die strategiese oogmerk vir die vervoerindustrie en 'n literatuuroorsig van Vervoerowerhede op munisipale regeringsvlak. Verteenwoordigende modelle vir strategiese bestuur en veranderingsbestuur, asook Swanepoel (2001) se bestuursmodel wat aangewend word vir die bestuur van verandering in die openbare sektor, word bespreek. 'n Geïntegreerde strategiese bestuursmodel, wat die grondslae van strategiese bestuur en veranderingsbestuur inkorporeer, word voorgestel om die stigting van Vervoerowerhede te stuur. Hierdie bestuursmodel bestaan uit ses fases, naamlik: Bewuswording en Mobilisering; Strategiese Analise en Keuse; Strategie Formulering; Strategie Implementering; Prestasiemonitering en Hersiening; en Stabilisering. Aanbevelings word gemaak rakende die bekragtiging van die model in 'n proefprojek.

Macro-economic theory, as postulated in Moving South Africa (1999), suggests that productive infrastructure is one of several key preconditions for sustainable economic growth. The theory furthermore holds that by investing in transport infrastructure such as roads, railways, airports and ports, a country can structure development, thereby reducing transport costs, facilitating trade and creating wealth. Providers of transport services and owners of transport infrastructure are well aware of the fact that transport as a derived demand is an industry in itself. This industry accounts for a substantial number of jobs in the national economy and has suppliers and customers of its own. The realisation of this macro-economic principle of productive infrastructure requires amongst other things the construction and maintenance of the transport infrastructure, as well as the existence of well-managed institutional structures to ensure sustainable transport service delivery to customers.

The National Land Transport Transition Act (Act 22 of 2000) was promulgated in August 2000. One of the provisions of this Act is the establishment and operation of Transport Authorities. Transport Authorities are statutory bodies in the municipal sphere of government, which are established to provide transport infrastructure and services through grouping transport functions into a single, well-managed and focused institutional structure.

\section{PROBLEM STATEMENT}

The declaration of Transport Authorities in terms of the National Land Transport Transition Act is of strategic importance to the South African transport industry and economy as a whole. The formation of Transport Authorities requires the establishment of a new statutory body at the municipal government sphere, which is a fairly new concept in South Africa. Role players, therefore, will need to be

Requests for copies should be addressed to: C Geldenhuys, Department of Human Resource Management, RAU University, PO Box 524, Auckland Park, 2006 empowered to perform new roles and hence there is a need to develop a total politically acceptable integrated strategic management model to navigate the establishment of Transport Authorities. Currently a strategic management model, which integrates the core principles of change navigation, does not exist to steer the smooth establishment of Transport Authorities in South Africa.

\section{RESEARCH OBJECTIVE AND APPROACH}

The objective of this article was to develop an integrated strategic management model suitable for the effective navigation of the change journey in establishing Transport Authorities. Such a model is based on Swanepoel's (2001) generic integrated strategic management model that guides the management of change in the public sector. Furthermore, the integrated strategic management model developed in this article can be a generic guiding framework for municipalities, requiring only minor customisation when applying the model to the unique circumstances of a municipality.

The research, firstly, covered a description of the strategic intent for the transport industry and, secondly, a literature overview of Transport Authorities. Thirdly, representative sets of strategic management models and change navigation models were reviewed, followed by a critical assessment of Swanepoel's (2001) integrated strategic management model that is widely accepted and used in the management of change in the public sector. Transport leaders in the public and private sectors reviewed the final draft of this article.

\section{Strategic intent for the transport industry}

This section describes the vision for transport in South Africa, followed by some prominent recent developments in the transport industry. Additionally, some critical success factors are listed, the achievement thereof which will enable the successful realisation of the future intent set for the transport industry in South Africa. 
The White Paper on National Transport Policy of 1996 indicates the vision for South Africa's transport as follows: "Provide safe, reliable, effective, efficient, and fully integrated transport operations and infrastructure which will best meet the needs of freight and passenger customers at improving levels of service and cost in a fashion which supports government strategies for economic and social development whilst being environmentally and economically sustainable." (White Paper on National Transport Policy, 1996, p.3)

Moving South Africa (1999) is the 20-year strategic framework of the National Department of Transport to deliver on the vision set for the transport system in South Africa. Moving South Africa thus provides the transition from the White Paper on National Transport Policy of 1996 to delivery on the ground. According to Moving South Africa (1999), the key long term strategic challenges facing the transport sector in South Africa are urban and rural passenger transport; tourist and long-distance customers; special needs customers; and freight transport.

It is evident that Government regards transport as an enabling industry, one that exists not only to meet goals inherent to transport, but also to meet other pressing national and social non-transport goals such as economic growth, growing trade and increased social integration. Since 1994 the South African transport industry has been facing dramatic organisational restructuring. Several state assets have been, or are currently being, fully or partially privatised. The National Department of Transport restructured several functions into fully or partially self-funding and statutory agencies in order to convert certain elements of the operational activities of government into commercial agencies. The new land transport legislation has far reaching impact on the institutional structure for urban and rural transport planning, amongst other things creating Transport Authorities at the municipal sphere of government with substantial jurisdiction over transport aspects.

Provincial Departments typically co-ordinate and integrate planning efforts between the national and municipal spheres of government. New national transport legislation requires inter alia an increased emphasis on the promotion of public transport and addressing user needs. Different categories of municipalities have been established in accordance with the provisions contained in legislation such as the Local Government Municipal Structures Act (Act 177 of 1998). A radical redrawing of Local Government boundaries reduced the number of municipalities from 864 to 287 . The municipal sphere of government is responsible for the execution and co-ordination of metropolitan transport and land-use planning; the provision, maintenance and management of facilities and infrastructure (excluding national and provincial roads); and the management of public transport facilities.

Transport Authorities will need to deliver on the strategic intent set for the transport industry and therefore need to transform the vision for transport into reality. In order to meet this challenge, the critical success factors for realising the strategic intent set for the transport industry include amongst others the following:

- Alignment to support national and provincial transport goals.

- Ownership and buy-in from key role players regarding a vision for transport.

- A set of appropriate values in order to enable and guide consistent decision-making, problem solving and conflict resolution.

- A culture that promotes inter alia transparent and ongoing communication.

- A learning culture including the empowerment of Transport Authorities to build human skills and capacity.

- Co-operative governance, co-ordination and co-operation between: (a) the different spheres of government; (b) transport and other government line-functions such as landuse development; (c) those within transport particularly with regard to infrastructure programmes and public passenger transport strategies; and (d) the Transport Authority, transport operators and transport customers.

- A sustainable financing and funding framework.

- Transparency in allocating resources.

- The ability of the Transport Authority staff members to deliver efficient and effective transport services to customers, including the preparation of relevant transport plans such as an Integrated Transport Plan.

- Flexible and adaptive to external changes.

An overview of transport authorities

This section provides a brief overview of the key aspects relating to the establishment of Transport Authorities in South Africa. On an international level there are numerous examples of hybrid Transport Authorities in existence, which separate the policy and regulatory role of government from the operation of transport services. The Greater Vancouver Transport Authority in Canada is probably the closest match to the South African model.

The key characteristics regarding the establishment and operation of Transport Authorities in South Africa are summarised in Table 1.

The magnitude of change resulting from the establishment of Transport Authorities as discussed above, requires the implementation of a politically acceptable integrated strategic management model to steer the change process.

Overview of representative sets of strategic management and change navigation models

This section constitutes an overview of representative sets of strategic management and change navigation models, followed by a description of Swanepoel's (2001) integrated strategic management model that guides the management of change in the public sector.

\section{Strategic Management Models}

Different models for strategic management have been proposed to strategise and navigate change in an organisation. Some of the prominent models are summarised in Table 2 .

Given the mentioned research, it can be concluded that the main components of strategic management models are:

- Formulate the vision and mission of the organisation in order to develop the identity and positioning of the organisation.

- Conduct a thorough internal and external analysis of the organisation. The comprehensive external environmental analysis is carried out with a view to identify threats and opportunities, and the internal analysis is to record the strong points and weak points of the organisation.

- Develop tactical and operational objectives and make strategic choices, followed by the formulation of strategies and action plans together with target dates and the allocation of responsibilities. The determination of strategic options and evaluating the feasibility thereof form part of this component of strategic management.

- Generate organisation capacity that will ensure strategy implementation.

- Exercise strategic control and continuous improvement (total quality management) to evaluate the implementation and the relevance of the chosen strategy, as well as making corrective actions if required.

The abovementioned components are generally developed by means of a systems approach and communicated to all role players in a transparent and coordinated way. The analysis, formulation, implementation and evaluation of strategies are a continuous process that affects the strategic, tactical and operational levels of the organisation. 
TABLE 1

\section{KEY CHARACTERISTICS OF TRANSPORT AUTHORITIES}

\section{Institutional Form}

A Transport Authority is a legal entity or statutory body that is separate from the participating municipality/ies. The governing body of the Transport Authority consists of appointed councillors from the participating municipality/ies.

Discussion Document on TA Areas in Gauteng (2000). The professional, technical and administrative work necessary for the functioning of the Transport Authority may be performed either by the staff members of the municipality/ies concerned, or by a Transport Executive set up as a separate body under the control of the Transport Authority.

NLTTA: An Introduction to TAs (2001) NLTTA (2000).

NLTTA: An Introduction to TAs (2001). NLTTA (2000).

NLTTA: An Introduction to TAs (2001) NLTTA (2000)

Discussion Document on TA Areas in Gauteng (2000). A Transport Authority is obliged to: (1) prepare and implement transport plans; (2) develop land transport policy; (3) perform financial planning for land transport planning, infrastructure, operations, services, maintenance, monitoring and administration; (4) co-ordinate the movement of people and goods on land; (5) effect public consultation and participation; and (6) after a specified date, take responsibility for all aspects of government public transport service contracts.

\section{Founding Agreement}

The establishment of a Transport Authority requires the preparation of a written Founding Agreement between the MEC (member of the Executive Committee responsible for transport in the province) and the municipality/ies whose area of jurisdiction falls in the Transport Authority area. The Minister of Transport must also be a party to the Founding Agreement in relation to any issues for which the Minster provides financing.

\section{Steps to form a Transport Authority}

The participating municipality/ies should prepare a Business Plan containing a full motivation for the establishment of the Transport Authority covering, but not limited to the geographical area, functions, institutional model, proposals with regard to a Transport Executive, budget and financing and a Founding Agreement. The municipality/ies should consult continuously with the relevant province, adjacent municipalities and the Minister (if financing is to come from the national sphere of government) to obtain "in principle" agreement to the Business Plan. In the determination of the Transport Authority area, the MEC must consult with the MECs responsible for local government affairs and finance in the province. The municipality should obtain "in principle" agreement from its Council to proceed with the establishment of a Transport Authority. All parties should then sign the detailed Founding Agreement. The province should publish the completed Founding Agreement in the relevant Provincial Gazette and declare the area as a Transport Authority area. The Transport Authority should implement the provisions of the Founding Agreement.

TABLE 2

STRATEgiC MANAGEMENT MODELS

\begin{tabular}{|c|c|}
\hline Contributor & Components of model \\
\hline Rue \& Holland (1989) & $\begin{array}{l}\text { This model consists of five steps, namely: (1) Status } \\
\text { quo analysis; (2) Investigate possible opportunities } \\
\text { for the future; ( } 3 \text { ) Identify and map the future; }(4) \\
\text { Implement strategies; and (5) Evaluate and manage } \\
\text { strategies. }\end{array}$ \\
\hline $\begin{array}{l}\text { Thompson \& } \\
\text { Strickland (1992) }\end{array}$ & $\begin{array}{l}\text { This process comprises of five interrelated } \\
\text { components, namely: (1) Defining the business and } \\
\text { developing a mission; (2) Setting objectives; } \\
\text { (3) Crafting a strategy to achieve the performance } \\
\text { objectives; (4) Implementing and executing the } \\
\text { strategy; and (5) Evaluating performance, reviewing } \\
\text { the situation and making corrective adjustments. }\end{array}$ \\
\hline $\begin{array}{l}\text { Dobson \& Starkey } \\
\text { (1993) }\end{array}$ & $\begin{array}{l}\text { This model consists of eight components, namely: } \\
\text { (1) Strategic history; (2) Current strategy; (3) } \\
\text { Environmental analysis; (4) Organisational analysis; } \\
\text { (5) Stakeholder analysis; (6) Strategic vision; } \\
\text { (7) Chosen strategy; and (8) Realised strategy. }\end{array}$ \\
\hline $\begin{array}{l}\text { Johnson \& Scholes } \\
\text { (1993) }\end{array}$ & $\begin{array}{l}\text { This framework consists of three main elements that } \\
\text { are integrated and inter-dependent, namely: (1) } \\
\text { Strategy analysis; (2) Strategy choice; and } \\
\text { (3) Strategy implementation. }\end{array}$ \\
\hline $\begin{array}{l}\text { Hampden-Turner } \\
\text { (1993) }\end{array}$ & $\begin{array}{l}\text { This model is based on opposite elements that } \\
\text { represent contrasting principles, which are reconciled } \\
\text { through corporate strategy. The contrasting principles } \\
\text { are: (1) Designed strategy versus Emergent strategy; } \\
\text { (2) Competitive positioning versus Adaptive co- } \\
\text { operation; (3) Rational competence versus } \\
\text { Evolutionary increments; (4) Deviance correction } \\
\text { versus Deviance amplification; and (5) } \\
\text { Opportunities/potentials versus Standards/rewards. }\end{array}$ \\
\hline Hill \& Jones (1995) & $\begin{array}{l}\text { This process consists of five steps, namely: (1) } \\
\text { Develop mission and objectives; (2) Decide on a } \\
\text { strategic choice based on an internal and external } \\
\text { analysis; (3) Formulate strategy on various levels } \\
\text { within the organisation; (4) Implement strategy; and } \\
\text { (5) Feedback. }\end{array}$ \\
\hline
\end{tabular}

NLTTA: An Introduction to TAs (2001) NLTTA (2000).
Leidtka \& Rosenblum This model addresses factors internal and external to (1996) $\quad$ the organisation, namely: (1) Organisational competencies (what can we do?); (2) Values of key implementers (what do we want to do?); (3) Industry threats and opportunities (what might we do?); and (4) Societal responsibilities (what ought we to do?).

Pearce \& Robinson This model consists of eleven key components, (2000) namely: (1) Company mission; (2) Internal analysis; (3) External environment; (4) Strategic analysis and choice; (5) Long-term objectives; (6) Generic and grand strategies; (7) Action plans and short-term objectives; (8) Functional tactics; (9) Policies that empower action; (10) Reengineering; and (11) Strategic control and continuous improvement.

Sveiby (2002) and Kaplan \& Norton (1992)

A company measures its performance through indicators linked to the strategic objectives of the firm and covering four major focus perspectives, namely: (1) Financial; (2) Customer; (3) Internal business processes; and (4) Learning and Growth.

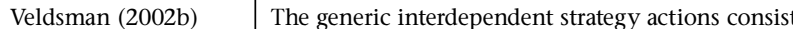
of a strategic map of main elements linked to four interrelated actions, namely: (1) Exploration and direction setting; (2) Bonding and commitment; (3) Steering and navigation; and (4) Tracking and assessing.

The seven main elements of the strategy map as outcome of the strategising process actions are: (1) Business mission (or definition); (2) Core competencies of the business; (3) Competitive edge; (4) Core philosophy; (5) Critical business performance measures; (6) Core strategy; and (7) Business vision.

This strategising process considers both the business and the operating environments. Two processes occur simultaneously. The one process is bottom up and organic and consists of five elements, namely: (1) Stakeholder experiences; (2) Stakeholder response; (3) Organisational actions; (4) Organisational performance; and (5) Wealth creation/destruction. The other process is top down and systematic and also consists of five elements, namely: (1) Mission; (2) Vision; (3) Philosophy; (4) Strategic initiatives; and (5) Goals. 
Change Navigation Models

Different authors have developed change navigation processes and models. Table 3 summarises a representative set of such models.

\section{TABLE 3}

\section{Change navigation models}

\begin{tabular}{|c|c|}
\hline Contributor & Components of model \\
\hline Lippitt (1982) & $\begin{array}{l}\text { The classic unfreezing-change-refreezing model of } \\
\text { Lewin, as quoted in Robbins (1998), is customised to } \\
\text { a seven-step model, namely: (1) Develop a need for } \\
\text { change; (2) Establish a working relationship between } \\
\text { the client and change agent; (3) Diagnose systems } \\
\text { problems of the client; (4) Examine alternative } \\
\text { routes and goals; (5) Transform intentions into } \\
\text { change efforts; (6) Generalise and stabilise change; } \\
\text { and (7) Achieve an ongoing relationship. }\end{array}$ \\
\hline $\begin{array}{l}\text { Allaire \& Firsirotu } \\
\text { (1985) }\end{array}$ & $\begin{array}{l}\text { Six steps are required to ensure successful } \\
\text { transformation within an organisation, namely: (1) } \\
\text { Conduct a comprehensive diagnosis of the } \\
\text { company's existing alignment with the environment, } \\
\text { threats and opportunities; (2) Formulate a meta } \\
\text { strategy necessary for radical change; (3) Evaluate the } \\
\text { current structure and culture of the organisation; } \\
\text { (4) Define the objective/s of the structure and } \\
\text { culture of the organisation; (5) Develop a broad } \\
\text { agenda for radical change taking cognisance of } \\
\text { political support, the communication programme } \\
\text { and change agents; and (6) Stabilise the organisation } \\
\text { through appropriate leadership. }\end{array}$ \\
\hline Levy (1986) & $\begin{array}{l}\text { This model combines the forces, processes and } \\
\text { content of transformation. This is seen as large-scale } \\
\text { changes in the core processes, culture, mission and } \\
\text { philosophy or paradigm of the organisation. The } \\
\text { forces enabling change are seen as inputs into } \\
\text { the model. }\end{array}$ \\
\hline Nutt (1992) & $\begin{array}{l}\text { This planned change process consists of five stages, } \\
\text { namely: (1) Formulation; (2) Concept development; } \\
\text { (3) Detailing; (4) Evaluation; and } \\
\text { (5) Implementation. }\end{array}$ \\
\hline $\begin{array}{l}\text { Warrick, as quoted } \\
\text { French, Bell \& } \\
\text { Zawacki (1994) }\end{array}$ & $\begin{array}{l}\text { The six basics of managing change are: (1) Clarify in } \\
\text { reality and the need for change; (2) Develop a } \\
\text { results-orientated strategy for change; ( } 3 \text { ) Plan and } \\
\text { manage the change process; (4) Involve the key role } \\
\text { players in planning and managing the change } \\
\text { process; (5) Build in reliable feedback mechanisms } \\
\text { to monitor and manage the change process; and (6) } \\
\text { Assure that the enabling structures are aligned to } \\
\text { facilitate and reinforce the desired change. Three } \\
\text { main phases of change are distinguished, namely: } \\
\text { (1) Preparation for change; (2) Implementation; and } \\
\text { (3) Transition. }\end{array}$ \\
\hline $\begin{array}{l}\text { Porras \& Silvers, } \\
\text { as quoted in French } \\
(1994)\end{array}$ & $\begin{array}{l}\text { This model consists of four components, namely: (1) } \\
\text { Change intervention; (2) Organisational target et al. } \\
\text { variables; (3) Individual organisational member; and } \\
\text { (4) Organisational outcomes. Bowers \& Franklin, as } \\
\text { quoted in French et al. (1994) (\#) A survey-guided } \\
\text { approach is used for organisational development and } \\
\text { change management. A survey is done as part of an } \\
\text { iterative process to assess the current state of } \\
\text { organisational functioning and the effectiveness of } \\
\text { the activities introduced to adjust and correct } \\
\text { discrepancies being diagnosed in the intragroup } \\
\text { and/or systematic processes. }\end{array}$ \\
\hline $\begin{array}{l}\text { Berger, Sikora \& } \\
\text { Berger (1994) }\end{array}$ & $\begin{array}{l}\text { Organisational change is defined as the continuous } \\
\text { process of aligning the organisation with its } \\
\text { environment focussing on strategy, operations, } \\
\text { culture and reward. The classic unfreezing-change- } \\
\text { refreezing model of Lewin, as quoted in Robbins } \\
\text { (1998), is customised to provide for five phases, } \\
\text { namely: (1) Change triggers; (2) Destabilise existing } \\
\text { business situations; (3) Reassess alignment with } \\
\text { market; (4) Change decision; and (5) Stabilise } \\
\text { change plan. }\end{array}$ \\
\hline Kotter (1995) & $\begin{array}{l}\text { Eight steps make up the transformation process, } \\
\text { namely: (1) Establish a sense of urgency; (2) Form a }\end{array}$ \\
\hline
\end{tabular}

powerful guiding coalition; (3) Create a vision; (4) Communicate the vision; (5) Empower others to act on the vision; (6) Plan for and create short-term wins; (7) Consolidate improvements and produce more change; and (8) Institutionalise new approaches.

\begin{tabular}{l|l}
\hline Tichy (1996) & $\begin{array}{l}\text { Organisational transformation implies large scale and } \\
\text { total organisational change, which is known as a } \\
\text { corporative revolution consisting of three elements, } \\
\text { namely: (1) Realising the need for change; (2) } \\
\text { Visualising a vision and mobilising people to achieve } \\
\text { the desired vision; and (3) Reengineering. }\end{array}$ \\
\hline Bowman \& Jarett & $\begin{array}{l}\text { This input-transformation-output model, which is } \\
\text { used to identify key issues to be addressed in the } \\
\text { change process, is based on the systems approach } \\
\text { and consists of three components, namely: (1) } \\
\text { Inputs; (2) Transformation; and (3) Outputs. }\end{array}$ \\
\hline Tushman \& O'Reilly & $\begin{array}{l}\text { Managing change involves moving an organisation } \\
\text { from its current state to its desired future state } \\
\text { through a transition period. The present and future } \\
\text { states of the organisation are described in terms of } \\
\text { four organisational building blocks, namely: (1) } \\
\text { Critical tasks and workflows; (2) Formal } \\
\text { organisational arrangements; (3) People; and (4) } \\
\text { Culture. The key issues to focus on during the } \\
\text { transition period are: (1) Power and politics; } \\
\text { (2) Individual anxiety and resistance to change; and } \\
\text { (3) Losing control during the transition period. }\end{array}$ \\
\hline Veldsman (2002a) & $\begin{array}{l}\text { This integrated change navigation approach is } \\
\text { described in terms of a metaphor for change } \\
\text { navigation, namely a play. The heart of the play is: } \\
\text { (1) the Inner pattern, which is the transforming } \\
\text { four-dimensional organisational landscape with its } \\
\text { change theme and plots; (2) an Outer pattern } \\
\text { containing the change acts of Awakening, } \\
\text { Mobilisation, Conversion and Stabilisation, each } \\
\text { with its specific scope and action learning; (3) an In- } \\
\text { between pattern consisting of the psycho-social } \\
\text { dynamics, the stage upon which the change unfolds; } \\
\text { and (4) an Lateral pattern making up the change } \\
\text { roles, which are the actors in the play. }\end{array}$ \\
\hline and
\end{tabular}

Models for organisational change are usually distinguishable based on its methodology and approach, processes, focus areas for change, and the extent of change required. The systems approach requires that the essential properties of the organisation be taken as a whole assuming that each element in the system has an effect on the behaviour of the whole system. Therefore, when a system is taken apart it looses its essential properties. The planned change process type of models are characterised by a thoroughly planned process and transparent communication strategy, which are managed by an authorised and empowered person/s within the organisation. Problems within the organisation are jointly identified and solutions developed based on consensus during consultative working sessions. The focus of the unfreezing-change-refreezing approach is primarily on the preparation of the organisation for change, the implementation of change and, finally, the stabilisation and reinforcement of change. The survey guided approach requires surveys to be carried out to assess the current state of organisational functioning and the effectiveness of the activities used to adjust and correct processes.

Based on the abovementioned, it is concluded that change navigation models consist of phases dealing with:

- Preparation and Awakening, which involves the establishment of a competent leadership team and an acknowledgement of the need for change.

- Mobilisation, which entails the gearing up for the change journey in terms of a more detailed intention, indicating the involvement of people and the required abilities and resources.

- Conversion, which deals with assessing alternative strategic choices, formulating change actions for implementation and evaluating support systems. Strong emphasis is placed on the continuous management of the process, together with transparent and ongoing communication. 
- Stabilisation, which involves institutionalising change.

An Integrated Strategic Management Model to Manage Change in the Public Sector

Swanepoel (2001) has developed an integrated strategic management model to manage change in the public sector. This non-specific model is depicted in Figure 1 and comprises of five phases and sixteen steps, some of which can be executed simultaneously and others consecutively. Furthermore, this model recognises the principles of strategic management in the public sector and it integrates different approaches towards the navigation of organisational change.

A critical step in Swanepoel's (2001) model is that internal and external change agents must be appointed as members of a multi-disciplinary transformational leadership team to plan, facilitate and monitor the change process. Leaders and change agents must consolidate management and organisational behavioural competencies in an iterative approach towards the management of change. They must also acquire and demonstrate the necessary knowledge and skills to provide direction, empower, communicate, validate, advise and inspire people on organisational, group and individual levels. Furthermore, the change process requires a wellplanned and broadly consulted communication plan, structures and channels.

Swanepoel's (2001) research concludes that changes in the political, economic and socio-cultural environment in the South African public sector, the Constitution, new legal and policy frameworks, directives for transparency and inclusivity, as well as the required social, political and

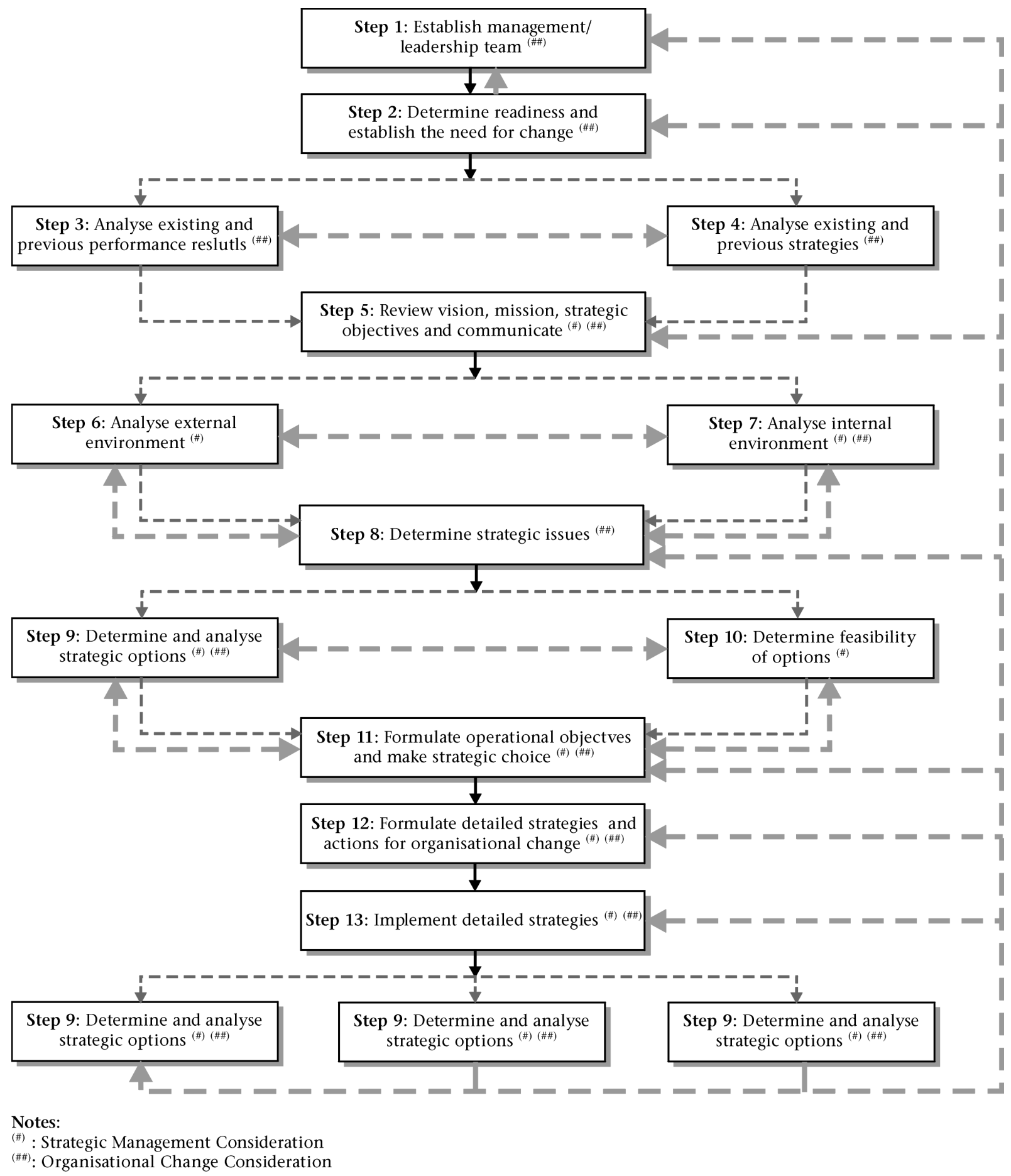

Figure 1: An Integrated Strategic Management Model to Manage Change in the Public Sector (Swanepoel, 2001) 
administrative organisational cultures have a strong impact on the process and content of management of change in the public sector.

An assessment of the integrated strategic management model to manage change in the public sector

The extent to which Swanepoel's (2001) model complies with the key abilities making up the core competence of strategic change navigation as suggested by Veldsman (2002a) is illustrated by crosses (8) in Figure 2 .

From Figure 2, it is evident that Swanepoel's (2001) model directly or indirectly compliments the elements of the five abilities of strategic change navigation suggested by Veldsman (2002a), namely:

- The ability to identify the necessary and essential organisation components, which must be changed as a result of the change need (the "what" of change): Swanepoel (2001) focuses particularly on changing the existing organisational culture.

- The ability to correctly define and position the change roles during the course of the change (the "who" of change):
Swanepoel's (2001) model combines a top down and bottom up approach to implement change. The formation of a multi-disciplinary transformational leadership team is suggested. Swanepoel (2001) is of the opinion that interventions occur in all three spheres of government. Provision is also made for all role players to be actively involved in the change process.

- The ability to fully understand and own the rationale for change (the "why" of change): Swanepoel (2001) is of the opinion that change has a major impact on the organisation as a whole, and that change is triggered because of compelling changes in both the internal and external environments.

- The ability to design, execute and track a sustainable and appropriate change process (the "how" of change): Swanepoel (2001) comprehensively covers communication that is necessary to steer the change process. There is also a strong emphasis on the change process (or journey).

- The ability to draw the requisite boundaries in space and time around an organisation (the "where" of change): Swanepoel's (2001) model follows a future-into-present and dynamic approach.

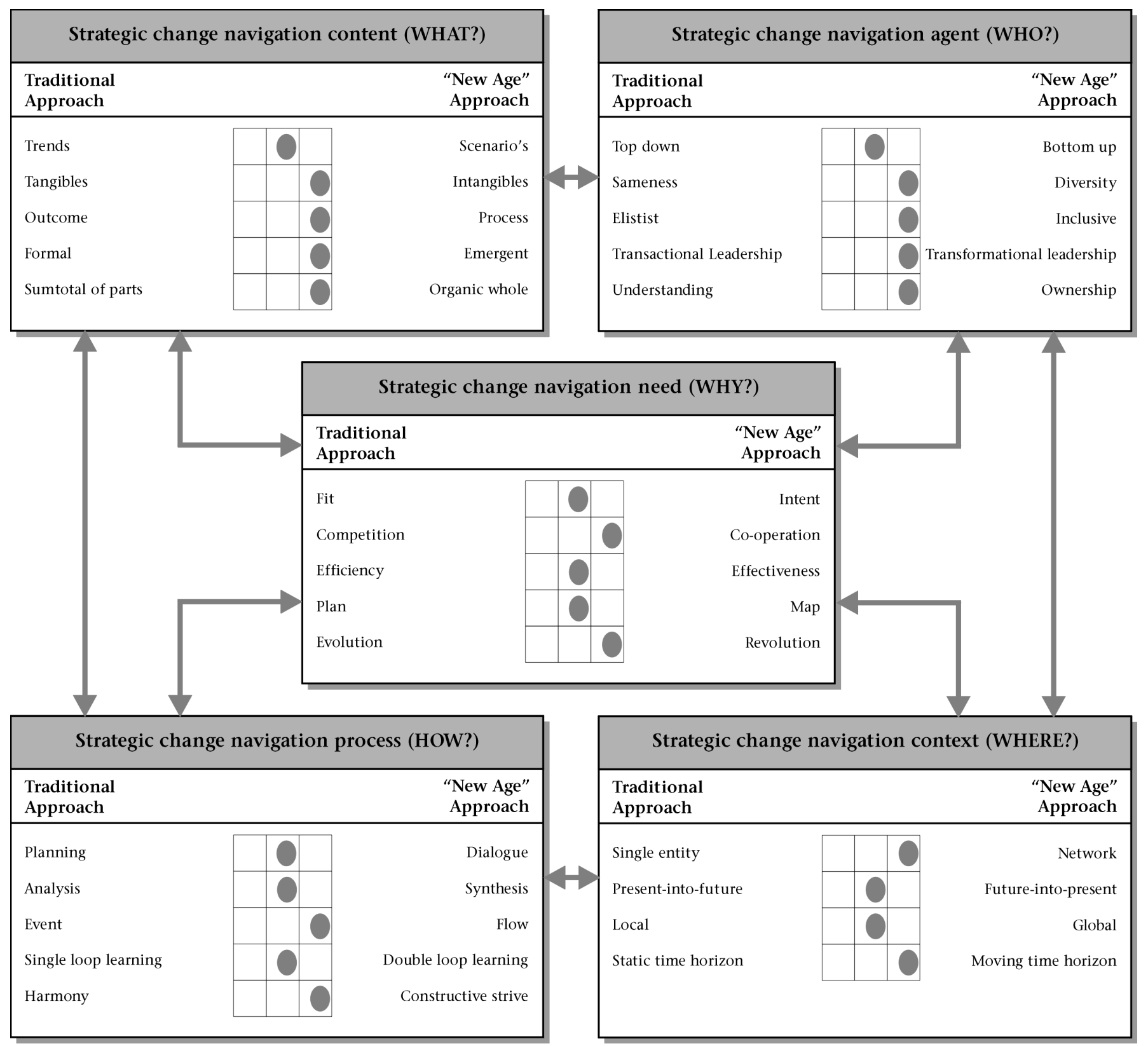

Figure 2: Assessment of Swanepoel's (2001) Integrated Strategic Management Model against the Key Abilities making up the Core Competence of Strategic Change Navigation suggested by Veldsman (2002a) 
The strengths of Swanepoel's (2001) integrated strategic management model are summarised below:

- Swanepoel (2001) considers both strategic management and organisational development and transformation as approaches towards the management of change.

- The New South Africa milieu demands that institutional reform and development must comply with government's directives for change and transformation. Swanepoel's (2001) model clearly incorporates the directives and principles referred to in the White Paper on Transformation in the Public Sector, 1995. The Batho Pele principles of "putting people first" are applied by incorporating aspects such as consultation, openness and directives for transparency and inclusivity. Furthermore, Swanepoel (2001) considers the impact of changes in the political, economic and socio-cultural environments of the New South African public sector, the Constitution, legal and policy frameworks, as well as the required social, political and administrative organisational cultures when navigating change in the public sector. The concepts of organisational culture, leadership, power, authority, communication, ethics and the role of change agents were also considered during the development of this model.

- The impact of change on, and required consultation with, role players and interest groups as a whole is comprehensively covered and the principles thereof are incorporated in Swanepoel's (2001) integrated strategic management model.

- Swanepoel (2001) consulted widely during the development of the integrated strategic management model and studied at least 1024 source documents.

The weakness of Swanepoel's (2001) model with respect to the establishment of Transport Authorities is the fact that the model is too generic. It therefore requires customisation prior to applying it to a specific municipality in order to accommodate its own unique circumstances. There may thus be a need to combine some of the steps contained in Swanepoel's (2001) non-specific model or to add additional steps. The sequence of steps may change and steps to be addressed consecutively may need to be addressed simultaneously, and visa versa, to accommodate the strategic requirements of navigating the establishment of Transport Authorities.

\section{CUSTOMISATION OF THE INTEGRATED STRATEGIC MANAGEMENT MODEL}

The integrated strategic management model developed by Swanepoel (2001) required customisation to navigate the establishment of Transport Authorities, namely:

- An additional step was added to empower technical role players and political decision-makers on aspects associated with establishing Transport Authorities. This was necessary in order to create the ability in the municipality/ies to fully participate in the transformation process, as well as to enable the successful realisation of the future intent set for the transport industry in South Africa.

- The sequence of the step covering the "review of the vision, mission and strategic objectives" was changed in order for it to precede the "analysis of existing and previous performance results and strategies". This modification strengthens the future-into-present approach.

- The formation of Transport Authorities involves the establishment of a new institutional structure. A new vision (or strategic intent), mission and strategic objectives need therefore to be developed as opposed to reviewing the existing vision, mission and strategic objectives as suggested by Swanepoel (2001).

- The development of organisational values based on consultation with key role players received more emphasis, as values are the set of beliefs or operating principles that will guide organisational behaviour within the Transport Authority.
- Transport Authorities will be tasked with rendering transport services to customers. The analysis of the external and internal environments, therefore, focused only on the provision of services and not services and products.

- As culture will consciously and subconsciously shape the values, assumptions, perceptions and behaviour of groups and individuals within the Transport Authority, it was justified being addressed as a separate step.

- The phase covering both evaluation and stabilisation was split up into two separate phases, namely performance monitoring and review, followed by a separate phase dealing with stabilisation. This was because of the fact that the focus areas of evaluating strategy support systems and results (total quality management) differ from that of stabilising and institutionalising change with respect to establishing Transport Authorities.

The resulting integrated strategic management model is graphically summarised in Figure 3 . This model consists of six phases, namely: (1) Awareness and Mobilisation; (2) Strategic Synthesis and Choice; (3) Strategy Crafting; (4) Strategy Implementation; (5) Performance Monitoring and Review; and (6) Stabilisation. The different phases comprise of eighteen steps, some of which can be executed simultaneously and others consecutively.

\section{APPLICATION OF THE RESULTING INTEGRATED STRATEGIC MANAGEMENT MODEL}

The practical application of the integrated strategic management model, shown in Figure 3, focuses on steering the smooth establishment of Transport Authorities. The transport industry in South Africa is characterised by the fragmentation of the transport responsibilities of the different government spheres; inefficient co-ordination; and an unclear interpretation of national and provincial transport priorities. Fragmentation was the key theme of the pre 1994 dispensation. Furthermore, severe resource constraints exist such as insufficient funding, low levels of capacity; and a lack of relevant expertise. Empowerment will, therefore, be high on the agenda towards the establishment of Transport Authorities being able to address transport aspects adequately.

Phase 1: Awareness and mobilisation

Step 1 -Establish a multi-Disciplinary Transformational Leadership Team

The focus of this step is on the setting up of a representative multi-disciplinary Transformational Leadership Team in order to objectively and transparently navigate the establishment of the Transport Authority, as well as improving human, technical and knowledge capacities within the Transport Authority. This Team must include multi-disciplinary technical representation (transport, legal and financial experts) from the participating municipality/ies and selected representation from the province, or provinces if the Transport Authority area extends across provincial boundaries. It is important that members of the Transformational Leadership Team must have sufficient status in order to empower action. The Terms of Reference of the Team must be developed already at the outset of the change process. The process must provide for structured and ongoing strategic input and intervention from municipal political decisionmakers. The involvement of suitable external change agents for a specific time period must be considered.

Step 2 - Empower key role players on aspects associated with establishing a Transport Authority

The objective of this step is to build and empower human capacity (skills and knowledge) both at the level of the Transformational Leadership Team and within the municipality/ies itself, to enable the implementation of improved transport services to customers (users of transport services). 
PHASE 1: AWARENESS AND MOBILISATION

Step 1: Estalish ba Multi-disciplinary Transformational Leadership Team

Step 2: Empower key role players on aspects associated with establishing a Transport Authority

\section{$\downarrow$}

Step 3: Establish the readiness for change and develop a desire to establish a Transport Authority

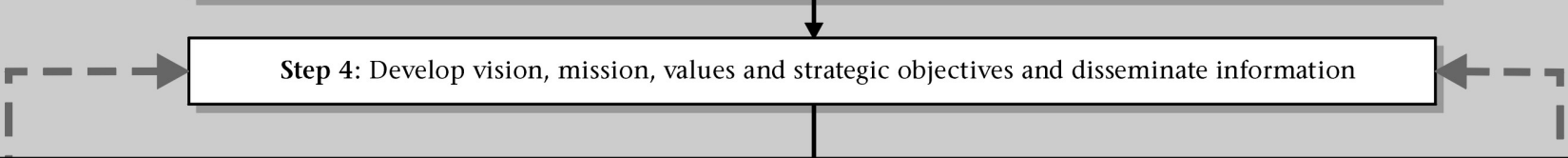

PHASE 2: STRATEGIC SYNTHESIS AND CHOICE

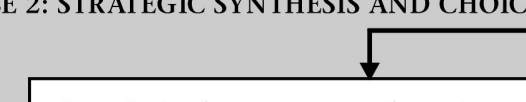

Step 5: Analyse current and previous performance results of the participating municpality/ies

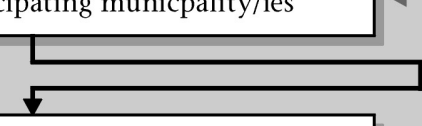

Step 7: Analyse external macron and micro environments

Feedback
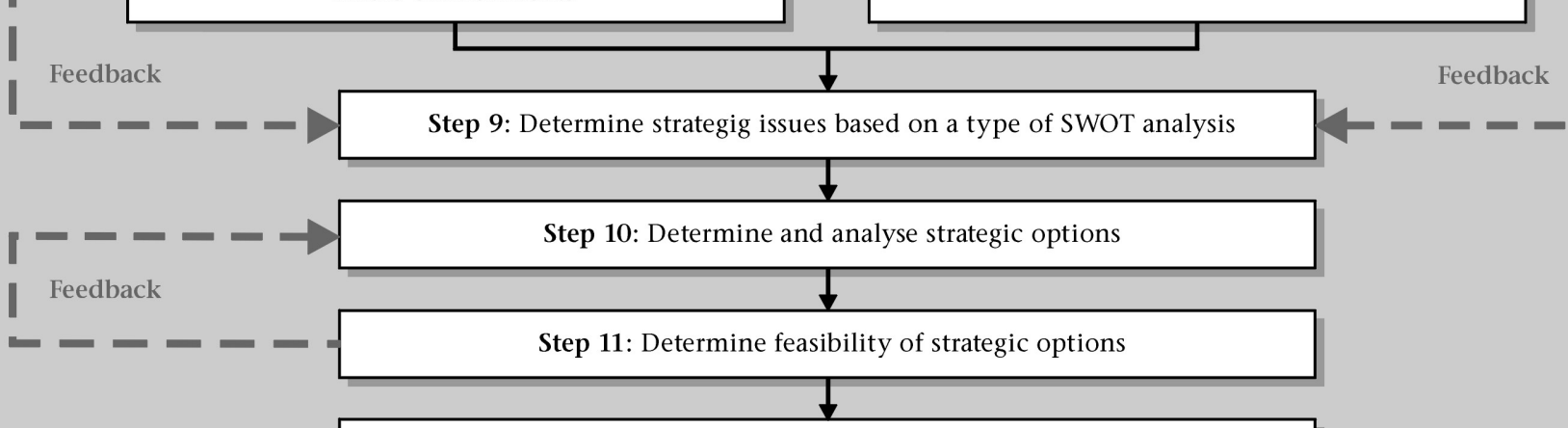

Step 8: Analyse internal environment

Step 6: Analyse current and previous strategies of the participating municipality/ies

Step 12: Make strategic choice and develop tactical and operational objectives

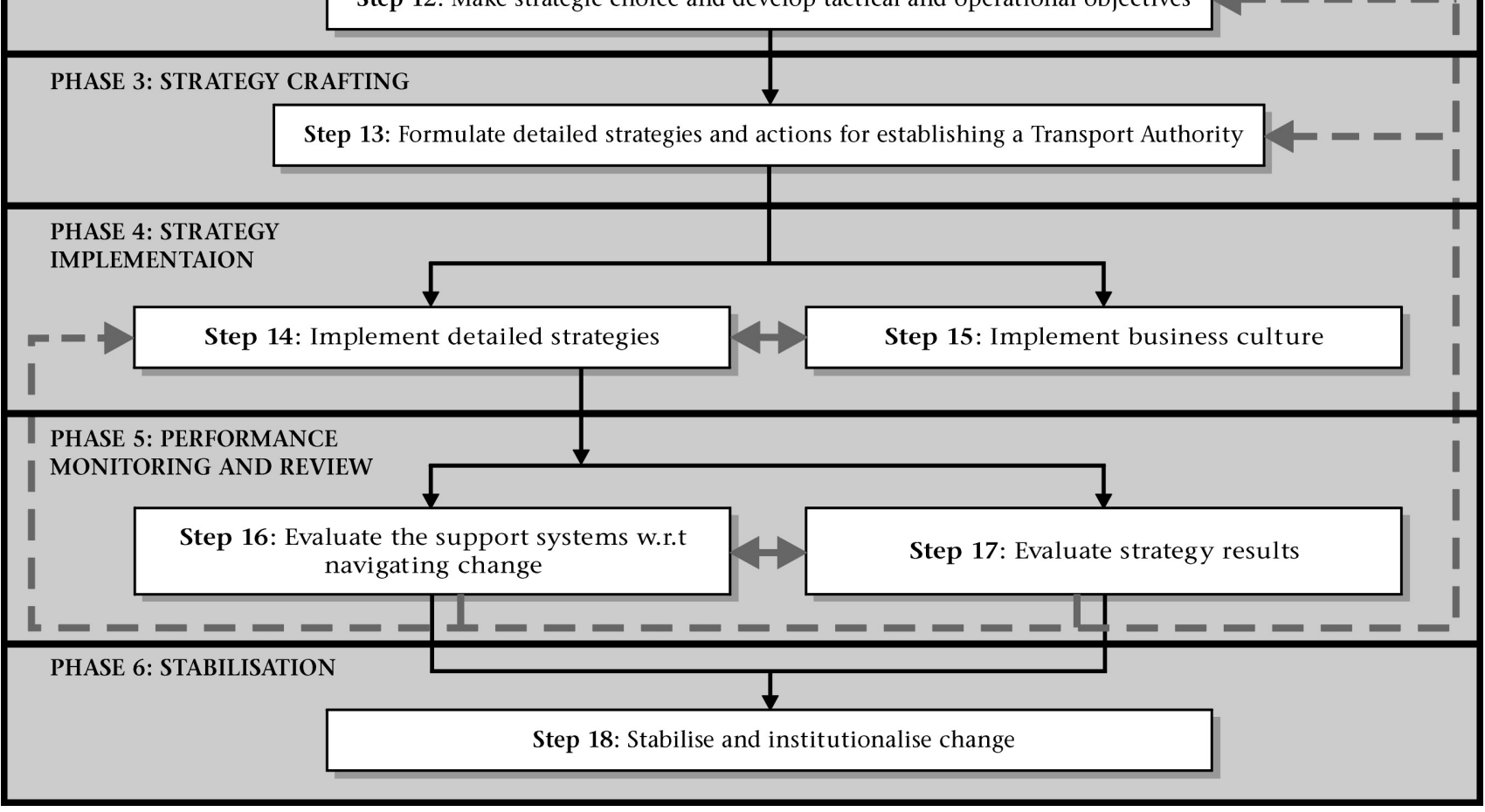

Figure 3: An Integrated Strategic Management Model to Navigate the Establishment of Transport Authorities 
Capacity building also entails creating the ability in the municipality/ies to fully participate in the transformation process or journey, such as the development of the vision, mission and supporting business culture. Aspects to be communicated to political decision-makers and technical role players during scheduled workshops must include inter alia the purpose of the Transport Authority, institutional form, roles and functions and the budgets and finances of the Transport Authority. Competent and experienced external change agents must preferably facilitate the empowerment of staff members and political decision-makers.

Step 3 -Establish the readiness for change and develop a desire to establish a Transport Authority

The Transformational Leadership Team must communicate with key technical role players and political decision-makers to assess the extent of their preparedness for change, assumptions, beliefs, the existing culture of the participating municipality/ies, as well as to evoke the need for establishing a Transport Authority. This awakening act thus pertains to a growing consciousness amongst staff members of the participating municipality/ies regarding the need for change. Broad opportunities must be jointly identified, as well as highlighting the disadvantages and risks of accepting the status quo. New mindsets have to be discovered and adopted, which will acknowledge the radical transformation and renewal of the participating municipality/ies into a new age Transport Authority, able to ride out the waters of change in a world of hyperturbulence. Key role players have to be convinced that future success looks different from past success; that the best way to predict the future is to invent it; and that the present and future are discontinuous and non-linear.

The following advantages will result from establishing Transport Authorities and must be communicated to all role players:

- the elimination of fragmentation regarding the provision of transport to customers;

- integrated transport service delivery across functions such as planning, infrastructure delivery, operations, regulation, performance monitoring and marketing; and

- the improved use of human resources and funding.

A possible challenge that is foreseen and which requires attention is the perception - of especially political decisionmakers - that the transport function can be performed by the existing municipality/ies, thereby negating the need for establishing a Transport Authority. Transport officials and political decision-makers must thus be provided with the necessary emotional support to enable them to make a success of the change journey.

Step 4 -Develop vision, mission, values and strategic objectives and disseminate information

The Transformational Leadership Team must communicate a clear, concise and agreed-upon vision, mission and strategic objectives for the future Transport Authority to the rest of the key role players based on consultative workshops. Values must be agreed upon to guide actions during the change. The vision, mission and strategic objectives must determine the focus of the external environment analysis (Step 7) and internal environment analysis (Step 8) regarding the type of management information to be collected for decision-making purposes. The implementation of Step 4 is characterised by members of the Transformational Leadership Team displaying strong leadership and communication skills to provide the necessary facilitation and navigation.

The development and implementation of a transparent communication strategy forms an integral part of Step 4 . The communication strategy must focus on all role players (including staff members of the participating municipality/ies) fostering a sense of commitment, sensitivity, awareness, understanding, support and involvement. Feedback and feedforward channels with wide frequency bandwidths must be set up to enable the continuous tracking of rapid changes during the rollout of the change.

According to Veldsman (2002a), the different parts of change should retain the coherence of the Transport Authority landscape, while simultaneously diverging from the "what is" state to the "what should/must be" state.

Phase 2: Strategic synthesis and choice

Step 5 - Analyse current and previous performance results of the participating municipality/ies

The performance of the participating municipality/ies during the current and previous financial years must be assessed against the initial objectives set for financial matters, people, transport services delivery, information systems, municipal restructuring, communication, general leadership and management, culture and logistics and supply chain management.

Step 6 -Analyse current and previous strategies of the participating municipality/ies

The broad strategies developed by the participating municipality/ies with respect to the aspects listed in Step 5 must be analysed. The strategies must be linked to the performance results obtained in Step 5 in order to assess the efficiency and effectiveness of the various strategies.

Step 7 - Analyse external macro and micro environments The analysis of the external environment serves to timeously identify opportunities and threats, as well as strategic issues that may support or restrain the Transport Authority from achieving its vision, mission and strategic objectives. The external environment comprises of the macro and micro (or operating) environments.

Macro environment: There are five dimensions within the macro environment that have an impact on the establishment and functioning of the Transport Authority. These dimensions, which must be analysed within the framework of the New South Africa milieu, are: (1) Politics (policies and ideologies of various role players); (2) Social or cultural (the diversity of values and cultures of role players); (3) Economy (reconstruction and development, growth, economic policies and priorities); (4) Institutional or juristic (institutional requirements, and national and provincial legislation dealing with transport and transformation); and (5) Technology (knowledge and innovation).

Micro (or operating) environment: There are four components of the micro environment that have a direct impact on the management and functioning of the Transport Authority. These four components that require analyses are: (1) Customers (users of transport services); (2) Regulatory (financial and human resources regulations); (3) Services providers (labour market and the provision of transport services); and (4) Competitors (private sector).

\section{Step 8 -Analyse internal environment}

Internal environment components: There are four components of the internal environment that will influence the management and functioning of the Transport Authority. These four components that require analysis are: (1) Organisational (objectives, strategies, organisational and institutional structures, administrative policies and procedures, administrative systems, reward system and ownership); (2) Human or social (capabilities, attitudes and perceptions, organisational culture, processes, social patterns, networking, individual and group characteristics, organisational behaviour and management styles); (3) Technological (equipment, posts design and description, workflow, technical policy and procedures, technical systems and logistics); and (4) Physical (location and physical layout of offices). 
Key performance areas: There are eight key performance areas that will have an integrated and holistic impact on the management, functioning and service delivery of the Transport Authority. These key performance areas that require consideration are: (1) Financial resources (budgets, assets, utilisation and costs); (2) People capacity (provision and development/empowerment of human resources, performance and rewards); (3) Services provision (transport services offered, provision of transport infrastructure and public transport facilities, and efficiency/ effectiveness of service delivery); (4) Communication (political acceptance, public satisfaction and internal and external communication); (5) Information management (information technology, knowledge management and management/ operational information); (6) Organisational culture (political, social and administrative cultures and ideologies and paradigms); (7) Organisational structure (delegation, relationship and linkages with national/provincial/municipal departments and committees); (8) Leadership and general management (strategies, networking, competencies and management functions); (9) Clients (markets); (10) Design systems; (11) Facilities; and (12) Technology (knowledge and innovation).

Step 9 -Determine strategic issues based on a type of SWOT Analysis The strategic issues must be relevant to the vision, mission and strategic objectives of the Transport Authority identified in Step 4, and must focus on management and organisational aspects that require change and/or analysis, particularly legal and ethical problems of strategic importance. Strong and weak points must be identified based on the results of Steps 5, 6 and 8. Threats and opportunities must be listed based on the results of Step 7.

Typical strategic issues regarding the challenges that Transport Authority staff members and political decision-makers will be faced with include:

- new operating and management environments;

- different priorities;

- increased responsibilities;

- cross-boundary Transport Authorities (municipal and provincial boundaries);

- availability of financing and funding; and

- an increased focus on service delivery.

Some risks include more direct accountability and increased exposure of Transport Authority staff members and political decision-makers to transport customers and role players.

Step 10 - Determine and analyse strategic options

Alternative and broad solutions must be developed to address the strategic issues identified in Step 9, including the identification and employment of existing internal competencies with a view to optimise external opportunities and to steer clear of external threats. Broad and overarching actions, programmes and projects must be identified in consultation with key role players in order to realise the integrated vision, mission and strategic objectives of the Transport Authority as identified in Step 4. Participation by key role players is extremely important and various consultative techniques can be employed such as participative workshops, brainstorming sessions, facilitating interviews, completing questionnaires and team building sessions.

Strategic options from the perspectives of both Transport Authority staff members and political decision-makers include:

- the extent of responsibilities to be adopted;

- the choice whether the functions of the Transport Authority should be performed by a Department of the participating municipality/ies or a Transport Executive; and

- the composition of the Transport Authority governing body.

Step 11 -Determine feasibility of strategic options

This step requires that the feasibility of the strategic options developed in Step 10 be considered in view of the availability of financial and human resources. Furthermore, the feasibility of the strategic options must be determined against: (1) economical considerations; (2) the efficiency and effectiveness of the strategic options; (3) affordability; (4) the implementation period; and (5) implementation risks.

Step 12 - Make strategic choice and develop tactical and operational objectives

There is a need to obtain maximum role player understanding of the new vision thereby securing alignment between the vision and the strategic choice to be made. Once agreement has been reached on the preferred strategic choice for implementation, measurable tactical and operational objectives must be developed. This will guide the development of appropriate strategies in Step 13, which in turn will enable the Transport Authority to achieve its tactical and operational objectives, as well as its vision, mission and strategic objectives identified in Step 4.

Once role player agreement has been obtained on over-arching aspects such as the gains associated with establishing a Transport Authority, the extent of decreased autonomy and the funding and financing mechanisms, only then must a Motivating Memorandum be prepared followed by a Founding Agreement as required in terms of the National Land Transport Transition Act (Act 22 of 2000). The Founding Agreement - signed by all relevant parties - must thereafter be published in the relevant Provincial Gazette, after which the Transport Authority area must be declared.

The process of making the strategic choice and developing tactical and operational objectives is illustrated in Figure 4. This figure supports the viewpoint of Veldsman (2002a), which states that change as process encompasses the conversion of the "what is" state into the "what should/must be" state, where "state" refers to the mode of existence and functioning of the Transport Authority.

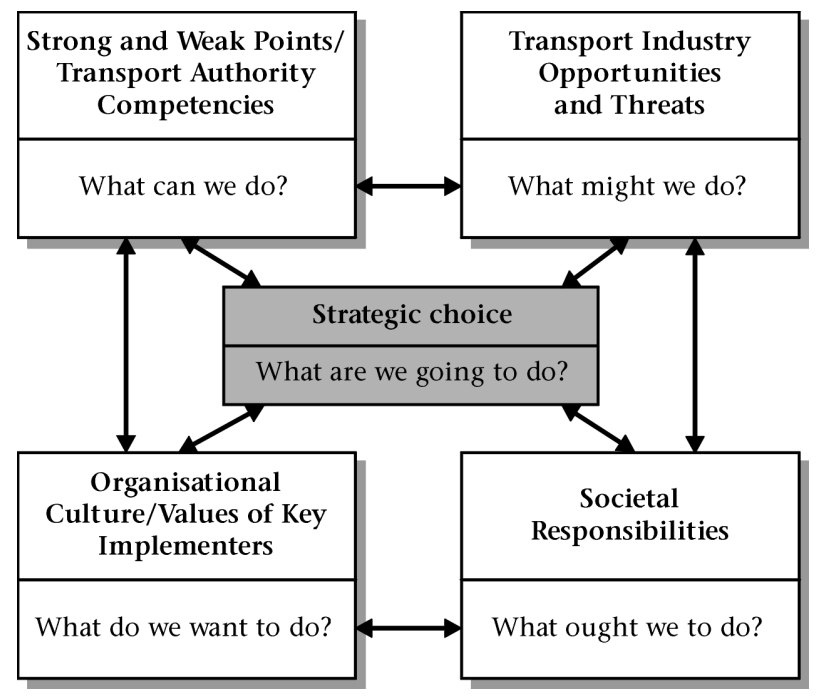

Figure 4: Process of making Strategic Choice (Leidtka \& Rosenblum, 1996)

Phase 3: Strategic crafting

Step 13 -Formulate detailed strategies and actions for establishing a Transport Authority

This step focuses on the planning of actions necessary to achieve the strategic objectives developed in Step 4, and tactical and operational objectives developed in Step 12. Detailed and flexible action plans, programmes and projects, together with time frames and the allocation of responsibilities, must be developed based on consultation with key role players. These detailed strategies and actions will assist in creating alignment between the various role players, thereby ensuring that the 
vision can be implemented in a coherent, integrated fashion and the current level of fragmentation in the transport industry dramatically reduced.

\section{Phase 4: Strategy implementation}

Step 14 -Implement detailed strategies

Veldsman (2002a) describes this step as a conversion process whereby sets of specific interventions are being rolled out across the organisational landscape in order to bring about a different mode of existence and functioning within the landscape. In other words, making the "what should/must be" state a reality in order to provide the Transport Authority with a certain configuration and trajectory.

Implementation of change must be driven through a process of concerted collective efforts by the key role players in transport under the leadership of the Transformational Leadership Team. Appropriate financial and human resources, which are supportive of implementing the strategies, must be established such as the allocation of budget, appointment of key staff members and empowerment and development of competencies, as well as the allocation of resources and monitoring the effectiveness of resource utilisation. Administrative support systems must be established such as appropriate policies, procedures and systems encouraging productivity. Reward and recognition incentive schemes, which are related to performance measurement, must be developed such as the provision of incentives to support strategy implementation, reward supportive behaviour and the promotion of goalorientated performance. Members of the Transformational Leadership Team must consequently demonstrate strategic leadership such as to guide the process of strategy implementation, consultative and joint decision-making, and transparent communication.

\section{Step 15 - Implement business culture}

One of the most significant challenges facing the Transformational Leadership Team is the establishment of a new organisational culture. Culture refers to the way a group of people sees things, thinks and does things. It is a way of life shared by members of a group that older members pass on to new members. Culture will cause the staff members of the Transport Authority to see reality very differently from each other and will cause each individual to believe that his or her perception of reality is the only rational way of seeing, thinking and doing things.

Marquardt (2000) is of the opinion that the new business culture involves: (1) a new vision; (2) mind-set; (3) values; (4) activities; and (5) leaders (mentors):

- Vision: The vision, which has been developed in Step 4, is the image and dream that is transmitted inside and outside the Transport Authority. It paints a picture of the direction for the future and represents the dreams that pull people forward. Senior management must work hard to communicate the vision and to publicly declare their commitment to realisation of the vision.

- Mind-set: The creation and sharing of a mind-set amongst staff members throughout the Transport Authority at both the individual and collective levels is a predisposition that will direct people to see the world in a particular way. Various programmes for building appropriate mind-set thinking and skills exist such as orientation programmes, seminars, conferences and cross-cultural and multicultural skills training.

- Values: Values or ethical standards are what is meaningful and what provides purpose and reason for what one does. The shared values must guide the strategic thinking, processes and procedures of the Transport Authority. Some examples of such values are: continuous learning that is highly valued and rewarded; a focus on total quality management and customer service; and a belief that people are important and should be respected and empowered through training.
- Activities: A culture contains a variety of activities and norms that externalise and reinforce the desired internal values, mind-sets and basic assumptions. The Transport Authority must simplify procedures and processes by for example implementing duplication elimination and valueadding assessment.

- Leaders (mentors): The Transport Authority must identify appropriate and competent leaders or mentors to build future leaders via mentoring, training and development. These leaders must be empowered and enabled to manage competitiveness, complexity, adaptability, teams, uncertainty and learning.

\section{Phase 5: Performance monitoring and review}

Step 16 - Evaluate the support systems with respect to navigating change

The support basis and systems relevant to the individual, groups and Transport Authority as a whole must be measured and evaluated (total quality management) and corrective actions implemented, if required. Continuous diagnosis of the staff members' emotional response and possible resistance to the unfolding change in the participating municipality/ies must occur. The implementation of appropriate actions (feed-forward and feedback communication and skills and knowledge capacitation) will ensure the elimination of stumbling blocks and hence the successful and continuous navigation of change.

Step 17 - Evaluate strategy results

Appropriate management information must be regularly gathered and used to monitor the implementation process. Actual results must be compared with the expected results (the strategic objectives developed in Step 4 and the tactical and operational objectives developed in Step 12) and prearranged performance criteria with a view to highlight irregularities and to introduce corrective actions, if required. Comparing actual results with expected results may require that Steps 4, 9, 12, 13 and 14 be reviewed as part of the iterative and continuous planning process.

\section{Phase 6: Stabilisation}

Step 18 - Stabilise and institutionalise change

According to Veldsman (2002a), the goal of the stabilisation process is to embed the chosen configuration and trajectory relatively permanently, but from the point of ongoing "unfreezing". Change at different levels and in various areas of the Transport Authority, as well as for different staff members, carries different meanings. Change as a process and outcome therefore has to be repeatedly localised and customised to fit a level, an area and persons. Various techniques can be employed to stabilise the Transport Authority structure, systems and processes such as the presence of strong leadership; frequent information sessions and communication; rewards and recognition; and the enablement and empowerment of staff members.

\section{CONCLUSION}

The complexity of the post 1994 democratic integration process requires change of considerable magnitude. Fragmentation of policy in the pre 1994 dispensation, duplication of modes and resources and other inefficiencies are some of the key issues that Transport Authorities will have to deal with. Empowerment will, therefore, need to be high on the agenda.

An integrated strategic management model that acknowledges the principles of strategic management, and integrates different approaches towards change navigation, can lead to the successful and smooth establishment of Transport Authorities. This article therefore serves to develop an integrated strategic management model to navigate the establishment of new institutional structures in the municipal sphere of government. This model consists of six phases and eighteen steps, some of which can be executed simultaneously and others consecutively. 
Implementation of the integrated strategic management model may create some challenges, including:

- the limited availability of transport officials and political decision-makers to fully participate in the activities required by the comprehensive model may delay the implementation thereof;

- urban and rural environments within the jurisdictional area of a single municipality may create difficulties with respect to integrating and coordinating transport and land use planning; and

- cross-border Transport Authorities (municipal and provincial borders) may result in conflicting agendas and priorities.

The continuous management of the process by a knowledgeable and experienced Transformational Leadership Team - displaying the necessary insight and skills - is of critical importance. Furthermore, transparent and frequent communication and consultation with key role players to deal with inter alia the new organisational culture, any possible resistance to change and the empowerment and capacitation of staff members and political decision-makers will enhance the probability of a successful Transport Authority in its endeavour to realise the strategic intent set for the transport industry in South Africa.

It is recommended that the integrated strategic management model developed in this article should be used to navigate the establishment of a Transport Authority in a pilot project for a specific municipality. The model can then be adapted in view of the lessons learnt and thereafter used by other municipalities when establishing a Transport Authority for their respective areas of jurisdiction.

\section{REFERENCES}

Allaire, Y. \& Firsirotu, M. (1985). How to Implement Radical Strategies in Large Organisations. Sloan Management Review, Autumn, pp. 26-32.

Berger, L.A., Sikora, M.J. \& Berger, D.R. (1994). The Change Management Handbook. New York: IRWIN, pp. 7-32.

Bowman, C. \& Jarett, M.G. (1996). Management in Practice. California: Sage, p. 213.

Discussion Document on Transport Authority Areas in Gauteng. TCC Report: 1/2000. Gauteng Transport Co-ordination Committee. (2000), pp. A1-A3.

Dobson, P. \& Starkey, K. (1993). The Strategic Management Blueprint. New York: Harper \& Row, p. 4.

French, W.C., Bell, C. H. \& Zawacki, R. A. (1994), pp. 83, 267, 468.

Hampden-Turner, C.M. (1993). Dilemmas of Strategic Learning Loops (Chapter 14). Strategic Thinking: Leadership and the Management of Change. Edited by Hendry, J., Johnson, G. \& Newton, J. The Strategic Management Society. John Wiley \& Sons Ltd, pp. 336-338.

Hill, C.W.L. \& Jones, G.R. (1995). Strategic Management: An Integrated Approach. Boston: Houghton Mifflin, p. 8.

Johnson, G. \& Scholes, K. (1993). Exploring Corporate Strategy, Text and Case. Third Edition. Boston: Prentice Hall, p. 85.

Kaplan, R.S. \& Norton, D.P. (1992). The Balanced Scorecard Measures that drive Performance. Harvard Business Review, January-February, pp. 71-79.

Kotter, J.P. (1995). Leading Change: Why Transformation Efforts Fail. Harvard Business Review, 73 (2), pp. 35-158.
Leidtka, J.M. \& Rosenblum, J.W. (1996). Shaping Conversations: Making Strategy, Managing Change. California Management Review, (39) (1). Autumn, pp. 141-157.

Levy, A. (1986). Second Order Planned Change. Organisation Dynamics. Summer, p. 5-20.

Lippitt, G.L. (1982). Organisational Renewal: A Holistic Approach to Organisation Development. Boston: Prentice-Hall, p. 108.

Marquardt, M.J. (2000). The Global Advantage - How World-Class Organisations Improve Performance Through Globalisation. Gulf Publishing Company. Houston. Texas, pp. 62-89.

National Department of Transport. Moving South Africa - The Action Agenda. A 20-year Strategic Framework for Transport in South Africa. (1999). Issued by the Minister of Transport and the Department of Transport, p.3.

National Department of Transport. White Paper on National Transport Policy. (1996), p. 3.

National Land Transport Transition Act, Act 22 of 2000. (2000), pp. 16-17.

National Land Transport Transition Act, Act 22 of 2000: An Introduction to Transport Authorities. (2001). National Department of Transport, pp. 2-4, 21-23, 31-32.

Nutt, P.C. (1992). Managing Planned Change. New York: MacMillan, p. 39.

Pearce, J.A. \& Robinson R.B. (2000). Strategic Management: Formulation, Implementation and Control. Business Week. Seventh Edition. Irwin McGraw-Hill, pp. 11-15.

Robbins, S.P. (1998). Organisation Behaviour. Eight Edition. New Jersey: Prentice-Hall, p. 639.

Rue, L.W. \& Holland, P.G. (1989). Strategic Management. New York: McGraw-Hill, p. 31

Sveiby, K. (2002). Methods for Measuring Intangible Assets http://www.sveiby.com/articles/IntangibleMethods.htm.

Swanepoel, D.V. (2001). Die Bestuur van Verandering in die Publieke Sektor. (D. Phil Proefskrif). Stellenbosch: University of Stellenbosch.

Tichy, N. (1996). Simultaneous Transformation and CEO Succession: Key to Global Competitiveness. Organisation Dynamics. Summer, pp. 49-55.

Thompson, A.A. \& Strickland, A.J. (1992). Strategy Formulation and Implementation. Fifth Edition. Boston: IRWIN, pp. 3-4.

Tushman, M.L. \& O'Reilly, C.A. (1997). Winning Through Innovation. A Practical Guide to Leading Organizational Change and Renewal. Harvard Business School Press. Boston. Massachusetts, pp. 181-211.

Veldsman, T.H. (2002a). Into the People Effectiveness Arena. Navigating between Chaos and Order. Johannesburg. Knowledge Resources, pp. 47, 52-58, 61-62, 66.

Veldsman, T.H. (2002b). Strategy Crafting in a Hyperturbulent World: A Lost Cause? Presentation delivered at the $3^{\text {rd }}$ Annual Best Practices Strategy Symposium. 20 \& 21 August 2002. Midrand: South Africa, IIR. pp. 3-4, 7.

Acknowledged contributors:

Dr D.V. Swanepoel (Khuthele Projects (Pty) Ltd)

Mr O.A.W. van Zyl, PrEng (Khuthele Projects (Pty) Ltd)

Mr J.H. Venter, PrEng (Khuthele Projects (Pty) Ltd)

Mr J.C. Vorster, PrEng (BKS (Pty) Ltd)

Mr A.S. Geldenhuys (Free State Provincial Government)

Mr M. Krynauw, PrEng (Tshwane Metropolitan Municipality, Gauteng)

Mr L. Swanepoel (Ekurhuleni Metropolitan Municipality, Gauteng)

Prof C. Fouché (Rand Afrikaans University) 